\title{
Is the Legal Basis for Physical Therapist's Home-Based Rehabilitation Appropriately Prepared?
}

\author{
Won-Su Kim', Jun-Bum Shin², Hye-Lyeong Yun ${ }^{3}$ \\ ${ }^{1}$ Busan dong-gu Jasungdae Seniors Welfare Center, Busan, Republic of Korea; ${ }^{2}$ ONEXT Rehabilitation laboratory, Busan, Republic of Korea; ${ }^{3}$ Pusan \\ National University Yangsan Hospital, Busan, Republic of Korea
}

Purpose: This study examined the legal basis related to a physical therapist's home-based rehabilitation.

Methods: The policy data were referenced to the comprehensive plan for national health promotion and the guidebook Community Health Promotion Project issued by the Korea Health Promotion Institute and other institutes.

The legal data were referenced to the Bill information system on the National Assembly website.

Results: The physical therapist's home-based rehabilitation did not have a legal basis in the community-based rehabilitation project (CBR) of the HP 2020 project. On the other hand, according to the Home health care part of the community health promotion project that began in 2013, physical therapists were allowed to play a role from 2020 under Article 16-2 (Public Officials in Exclusive Charge of Visiting Health Management) of the REGIONAL PUBLIC HEALTH ACT.

Conclusion: Policies and laws are being developed in the field of healthcare, but the necessary policies and laws in the field of rehabilitation are still insufficient. A bill to rehabilitate in a variety of fields and spaces by modifying the scope of work of physical therapists will be needed.

Keywords: Home-based rehabilitation, Visiting physical therapy, IBR, CBR

\section{서 론}

'지역사회중심재활(community-based rehabilitation, CBR)'은 1978년 세 계보건기구(World Health Organization, WHO)의 알마타선언에 따라 시작되었다.' 2010년 세계보건기구의 'CBR Guideline-CBR MATRIX' 에서 제시된 내용에서는 '의료서비스중심에서 '건강-교육-생계-사회 적욕구-역량강화의 5 가지 주제를 기반으로 개별요소를 세분화하여 포괄적인 접근이 이루어지도록 하고 있다. ${ }^{2}$

보건복지부 또한 시설중심의 재활(Institution Based Rehabilitation, IBR)'에서 노인환자, 만성질환자 그리고 재활난민의 증가 등으로 인해 늘어나는 재가장애인의 문제해결을 위해 지역사회중심재활사업의 보건소를 중심으로 대책을 세워왔다. 특히, 재가장애인들에 대한 방 문재활의 필요성과 지원에 대해서는 이전의 연구들에서도 많이 제기 되어왔었다.4-8

우리나라 방문재활정책은 의료관련법에 기준을 둔 시설중심재활 보다는 1995년 국민건강증진법이 제정된 이후로 국민건강의 관점에
서 만들어진 정책에 따라 나누어진 여러 중점과제의 성과지표를 통 해 관리되어져 왔다. 국민건강증진법 제 5 조의 3 에 의해 설립된 한국 건강증진개발원에서 'Health Plan (HP2010; 1-2차 국민건강증진종합 계획, HP2020; 3-4차 국민건강증진종합계획)' 사업을 수립하여 수행 하고 있으며, 개별정책사업으로 '지역사회중심재활사업'과 '지역사회 통합건강증진사업(community health promotion project)'이 실시되고 있지만 구체적인 내용은 서로 중첩되어있다(Figure 1). ${ }^{9-12}$

1979년부터 시작된 미국의 'Health People, The Surgeon General's Report on Health Promotion and Disease Prevention'사업은 10년동안 달성 할 중점과제를 정하여 각급정부와 민간에 배포하여 정기적인 평가가 이루어졌으며, 1980-1990년대의 계획을 평가하고 목표를 정한 것으로 'Health People 2000'은 이후 사업영역이 늘어나고 중점과제들이 변하 였다. 이렇게 진행되어진 'Health People 2010-Health People 2020'을 우 리나라에서는 국민건강증진종합계획에서 'Health Plan: HP2010HP2020사업으로 벤치마킹하였다.9-12,15

HP2010 건강분야의 금연, 절주, 영양과 더불어 운동과제가 HP2020
Received Aug 3, 2020 Revised Aug 27, 2020

Accepted Aug 28, 2020

Corresponding author Won-Su Kim

E-mail scar9406@naver.com
Copylight (C)2020 The Korean Society of Physical Therapy

This is an Open Access article distribute under the terms of the Creative Commons Attribution Non-commercial License (https:// creativecommons.org/license/by-nc/4.o.) which permits unrestricted non-commercial use, distribution, and reproduction in any medium, provided the original work is properly cited. 

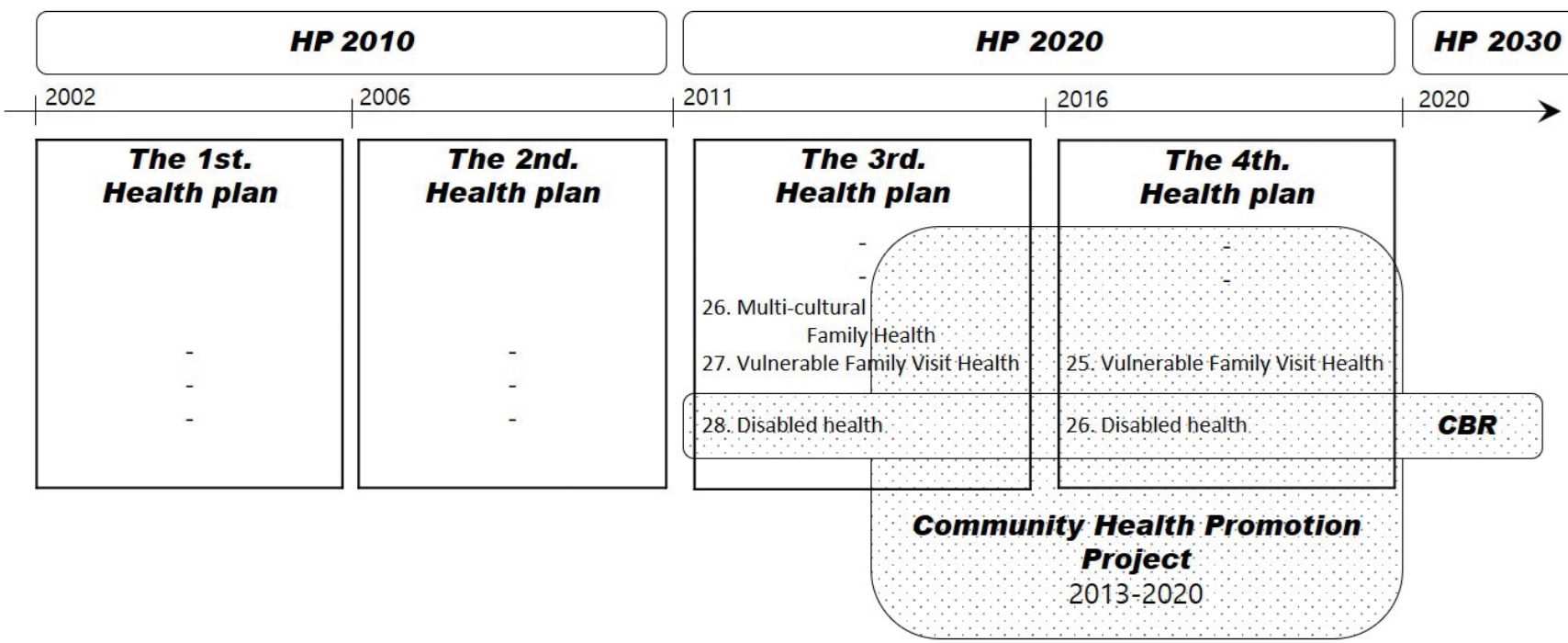

Figure 1. Health policies related to home-based rehabilitation.

에서는 신체활동 과제로 바뀌어 제시되었지만 물리치료사의 역할은 언급되지 못하였으며, 방문재활에서 물리치료사의 역할이 포함된 것 은 건강관련습관과 같은 결정요인의 실행적 측면이 포함된 HP2020, 특히, 3 차 국민건강증진종합계획부터이다.

HP2010-HP2020사업은 만들어진 법률에 근거해서 추진되어진 사 업이 아니라 미국의 Health People을 벤치마킹을 한 영향도 있으며, 환 자가 대상이 아니라 국민들의 건강관리에 대한 시범사업의 개발이 여러 과제에 따라 업무지침들로 나누어서 추진된 사업이다. 이렇게 개발된 사업내용에 대하여 서로 다른 법률들로 근거를 두어서 사업 추진의 책임과 의무, 담당인력의 문제등이 매년 조금씩 변경되어 계 속 정리가 되고 있는 중이다. 이전의 연구들에서 방문재활을 포함한 물리치료사의 참여가 다양하게 요구되고 있지만, 보건의료관련법을 벗어난 건강, 복지분야 등에서의 재활에 참여하는 물리치료사의 법 률적 근거는 보강되어야할 부분이 많이 있다. ${ }^{16-18}$

대한물리치료사협회에서 발행한 재가방문물리치료에 대한 실무 지침과 가이드라인'에서도 법률적 근거는 아직 마련되어 있지 않으 며, 지역사회중심재활이라는 큰 사업아래에서 여러 사회분야의 요구 에 의해 물리치료사의 참여가 세분화되다 보니 실무지침과 가이드 가 명확하게 규정되지 못 하였다. ${ }^{19,20}$

지역사회중심재활과 지역케어회의 등 지역중심으로 재가장애인 들과 노인들 등에 대한 건강관리 및 보건에 관심이 증가되고 있는 가 운데 방문재활, 방문물리치료에 대한 필요성은 논의되어 왔었지만 해당사업의 법적 근거는 적합하게 준비되지 않고 있다. 본 연구에서 는 최근 국회에서 방문재활, 방문물리치료의 내용으로 발의된 법안 을 조사하여 방문재활, 방문물리치료에 대한 방향성과 입법에 있어 적합하게 준비되고 있는지를 알아보고자 한다.

\section{연구 방법}

\section{1. 자료수집}

본 연구는 급속히 증가하는 노인인구와 만성질환의 증가로 인한 방 문재활, 방문물리치료의 요구에 대해 효율적으로 준비되지 않은 현 행제도와 법률에 대한 근거자료를 통해 조사하였다.

보건복지부와 한국건강증진개발원에서 추진하는 사업과 더불어 매년 발행한 '국민건강증진종합계획 2010-2020'과 2013년부터 발행한 '지역사회통합 건강증진사업 안내서'와 '방문건강관리', '지역사회중 심재활등 개별안내서를 수집하여 문헌고찰을 하였다.

법률자료는 현행법률과 국회에서의 입법활동에 대한 부분을 알아 보기 위하여 '방문재활, '방문물리치료’ 라는 단어로 국회 홈페이지 등에서 검색을 하였었고, 국회홈페이지의 입법예고 시스템(http://pal. assembly.go.kr/search/mainView.do)을 방문하여 동일한 단어로 입법 예고된 의안자료를 검색하였다. 연구시점에는 입법예고시스템을 통 해 19-20대 국회의 입법안내용에 대해서만 자료검색이 가능하였으 므로 19-20대 국회에서 입법예고한 의안에 대해서 검색하여 최근 국 회에서의 방문재활, 방문물리치료에 대한 법률적 근거에 대하여 조 사하였다. 자료조사를 통해 개별사업의 내용과 근거법률들을 비교 하여 중복되는 내용과 사업내용에 비하여 부족한 근거법률을 조사 하여 확인하였다.

\section{2. 자료분석}

먼저 학술자료를 통해 발표된 내용으로 방문재활, 방문건강관리의 역사적 내용을 확인하였고, HP2010, 2020의 정책자료를 통해서 우리 나라 정책에서 방문재활이 건강관리분야 중심으로 이루어져 오게 
된 내용과 국가중심의 사업에서 지역사회 특성에 맞춘 지역사회통 합 건강증진사업으로 정책이 바뀌게 된 변화내용에 대해서 안내서 를 통해서 정리하였다. 이 가운데 HP2020사업과 지역사회통합 건강 증진사업에서 중첩되는 방문건강사업 그리고 지역사회중심재활 사 업들에서 물리치료사가 재활전문가로서 역할을 담당할 수 있는지 근 거법률을 분석하였다. 지역사회중심재활사업과 지역사회 통합건강 증진사업에 대해서도 개별지침 및 안내서를 참고하였다.

입법예고 된 개별법안에서 제안이유와 기존법안과 개정안의 차이 를 분석하였으며, 제안된 내용과 다른 법안의 내용과도 비교하여 상 충되는 내용에 대해서 분석하여 보았다.

\section{결 과}

\section{1. 정책에서 방문재활}

한국건강증진재단에서는 분당서울대학병원과 함께 일본의 개호보 험을 참고해서 한국에서 적용가능한 방문재활서비스모델을 제안하 여 개발하였다. ${ }^{1421} 2002$ 년 '국민건강증진종합계획(HP2010)'을 시작으 로 뒤이어 '지역사회통합 건강증진사업(2013)'이 진행되었으며, 방문 재활과 관계된 개별사업으로 '지역사회중심재활'과 '방문건강관리사 업' 등이 포함되었다. 이들 사업들 중에서 '지역사회중심재활사업'에 서 '장애인건강보건관리사업'은 거의 동일한 내용임에도 구분되어서 관리되어 사업이 일원화되지 못하고 요구분야에 따라 분화되어져 있 음을 알 수 있었다.

노인장기요양보험 서비스내에서 방문재활서비스를 시범사업으로 하여 모델을 개발하고 단계적 방문재활서비스를 제안하여 중앙장애 인보건의료센터-지역장애인보건의료센터로 이어지는 사업수행체계 를 제안하여 지역중심재활사업에 반영되었다. ${ }^{1.21}$

\section{1) 국민건강증진종합계획(Health Plan, 2002-2020)}

HP2010 (1,2차 국민건강증진종합계획: 2002-2010)에서는 국민소득 2 만달러경제와 노인인구 비율이 $10 \%$ 대에 도달하는 시대를 맞아 건강 수명연장을 목표로 하였으나 현실적으로 달성하기 어려운 내용이었 고, HP2020 (3,4차 국민건강증진종합계획: 2011-2020)에서는 사회경제 적 계층간의 격차를 줄여 건강수명연장과 건강형평성 제고를 통해 온국민이 함께하는 건강세상을 목표로 하였다.9-12

Figure 1에서처럼 방문간호를 중심으로 이루어져 오던 인구집단건 강관리의 중점과제들에서 HP2020의 3차 국민건강증진종합계획부 터는 중점과제 26 번 다문화가족건강, 27 번 취약가정방문건강에 대한 중점과제들이 '방문건강관리'사업의 내용으로 포함되었고, 28 번 장애 인건강에 대한 중점과제가 '지역사회중심재활사업의 내용으로 첨가 되었다.1011 하지만 3차 국민건강증진종합계획은 '건강수명연장과 건
강형평성 제고'를 목표로 두고 있었기에 중점과제 26 번과 27번에서는 건강격차해소와 건강수준향상에 목표를 둔 '방문간호사'의 역할이 더욱 커지게 되었다.

\section{2) 지역사회통합 건강증진사업}

HP2020의 목표달성을 위하여 국가 주도형 사업방식에서 탈피하여 지 역별 다양한 특성과 주민수용에 맞는 건강증진사업을 기획, 수행하 여 2013년부터 시작한 사업이다. 보건소내외 사업을 통합연계하여 활 성화시키는 '방문건강관리사업과 국립재활원을 중심으로 하는 '지역 사회중심재활사업이 거의 동일한 사업으로서 중점관리하는 부서와 내용의 차이로 나뉘어져서 사업이 진행되고 있다. Figure 1에서 중점 과제 28. 장애인건강'은 '지역사회중심재활사업과 '방문건강관리'사업 에서 중첩되었지만 정책적인 측면에서 다른 부분으로 관리가 되고있 다. 이 방문건강관리사업과 지역사회중심재활사업들에서 물리치료 사의 주요역할이 다양하게 주어져 있으며 중복되는 부분도 있다.

\section{(1) 방문건강관리}

사회, 문화, 경제적 건강취약계층 및 65세이상 독거노인, 75 세 이상 노 인부부가구 중심을 대상으로 간호사, 영양사, 물리치료사, 작업치료 사, 치과위생사 등이 방문하여 건강관리서비스를 제공하는 방법으 로 운영하고 있다. 1990년 일부 지방자치단체의 보건소를 통하여 방 문보건사업을 부분적으로 실시하여 온 것부터 시작되었다. 2001년에 방문보건사업 표준지침이 개발되어 보급되었고 전국 보건소를 통해 방문보건사업이 전면적으로 실시되었다. 맞춤형 방문건강관리사업 이 진행되어오다 2008년 지역사회중심재활사업으로 통합 운영되어 왔었고, 2011년부터는 북한이탈주민 건강관리사업이 추가되었다. 2013년부터 지역사회 통합건강증진사업이 운영되면서 2018년부터는 별도 예산사업으로 분리되어 진행되고 있다. 물리치료사와작업치료 사는 대상자 및 집단 등에 재활상담 및 건강관리서비스를 제공하고 재활관련서비스를 제공하는 업무를 한다. ${ }^{12,13,22,23}$

\section{(2) 지역사회중심재활}

HP2020사업에서는 '장애인건강이라는 중점과제로 진행되는 사업이 2011년부터 '지역사회중심재활'이라는 제목으로 '지역사회통합 건강 증진사업 중 물리치료사가 함께 참여하고 있는 사업이다(Figure 2).'

(1) 중앙장애인 보건의료센터(국립재활원)는 보건복지부의 정책, 예산 등을 관리하고 장애인 건강사업과 교육과정개발, 통계구축 및 건강정보 등을 지역장애인보건의료센터에 제공한다.

(2) 지역장애인 보건의료센터(병원급이상 의료기관지정 총 19개소) 는 광역지자체에서 정책, 예산 등을 관리하고 유관기관 및 서비스 연 계, 조정 및 지원하고 검진과 재활 등 의료서비스를 담당한다. 권역재 

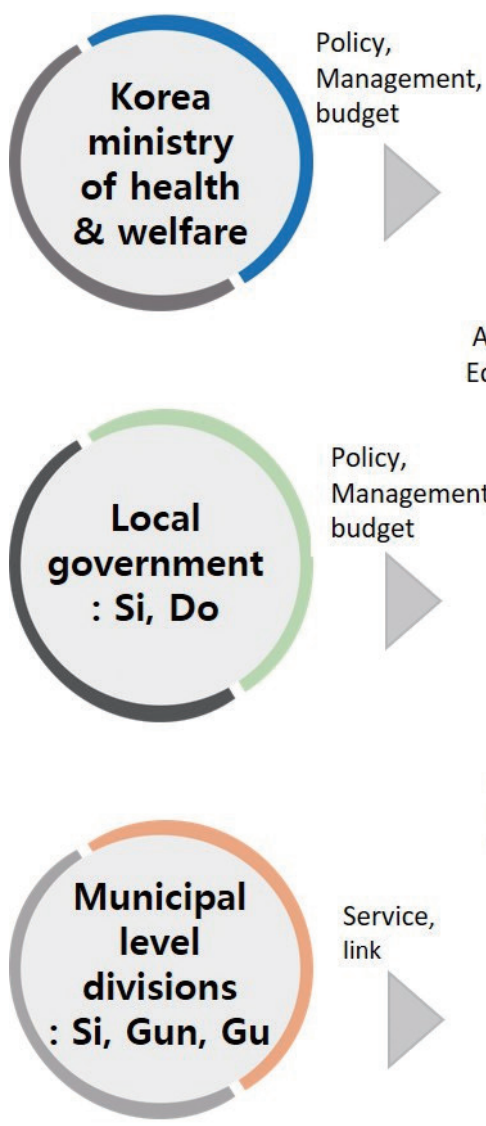

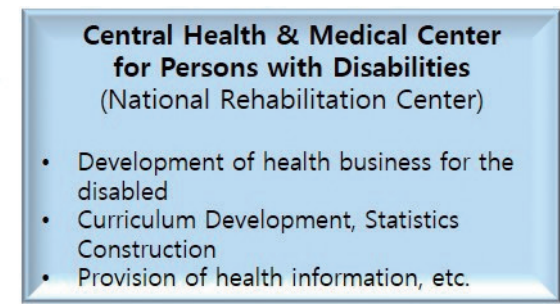
Administrative support
Educative support

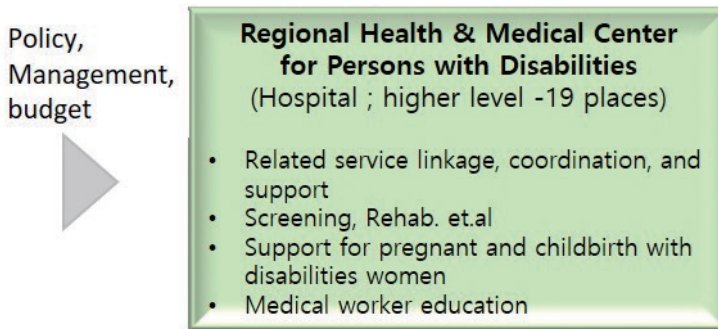

Administrative support Educative support Service support

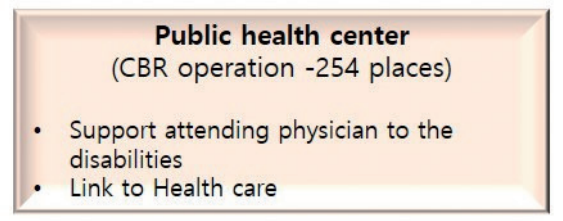

\section{District \\ Rehabilitation Hospital}

Rehabilitation

Medical institution

\section{Attending physician}

For the disabilities

Request

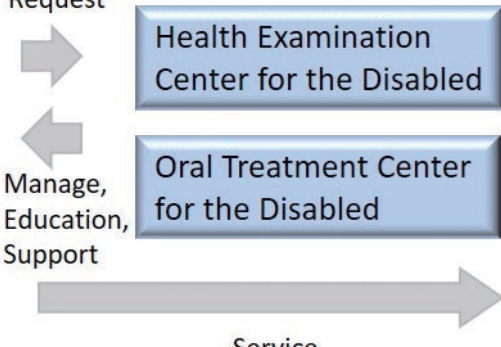

Service

Statist

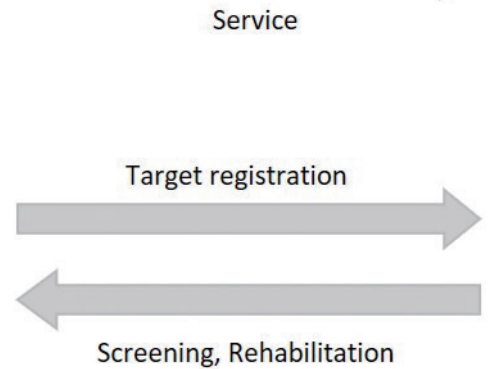

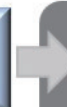

(1)

(a)
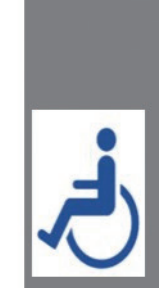

Figure 2. CBR promotion system.

활병원에서 방문재활서비스를 제공한다.

(3) 보건소(전국 254 개소 지역사회중심재활 운영)는 기초지자체에 서 대상자별 특화된 서비스를 제공하여 일상생활과 자립능력 증진 이 가능하도록 한다. 건강관리사업을 연계하여 의료인-주민-가족의 장애인식이 개선되도록 한다.

\section{(3) 장애인 건강보건관리(지역장애인 건강보건의료 및 재활의료사업에 대한 지원)}

지역사회중심재활사업의 내용을 포함하고 있으나 보건복지부에서 따 로 구분하여 전체사업을 관리하고 권역재활병원과 공공어린이재활 병원 및 장애인 의료재활시설에 대하여 지원한다. 방문재활에 있어서 는 '장애인 건강 주치의'와 '방문간호'사업이 시범사업으로 장애인 건강 권법과 시행령에 의해서 2018년 5월부터 시행되고 있으나, 장애에 대한 관리와 예방, 치료를 해당 전문의의 업무로 한정하고 있다. ${ }^{24}$ (1) 지체장 애: 재활의학과, 정형외과, 신경외과, 신경과, 내과(류마티스), (2) 뇌병변 장애: 재활의학과, 신경외과, 신경과, (3) 시각장애: 안과.

\section{2. 법적근거로서 방문재활}

방문재활, 방문물리치료라는 용어는 아직 법률적 용어가 아니다. 대 표적인 보건의료관계법인 의료법과 의료기사법에서도 방문재활과 방문물리치료에 대한 조문내용은 없기 때문이다. 많은 연구와 각종 단체와 시설에서 방문재활에 대한 요구가 있어왔지만 우리나라에서 는 제도적으로 방문재활보다는 방문간호를 중심으로 '방문건강관리' 사업이 진행되어왔다. 그러므로 방문재활은 독립적인 사업으로서 중 심이 되지못하였고 해당법령 또한 만들어지지 못하였다. ${ }^{26,27}$

1948년 세계보건기구 회원국이 된 이후, 1963년부터 지역분담제(통 합보건사업: District health services, Generalized community health services) 시범사업으로 충남 등에서 방문간호사업을 시작으로 1985년 통합보건사업을 전국적으로 확산시켰고, 이 과정에서 '통합보건요원' 이 만들어지게 되었다.

방문간호사업의 법적근거는 1995년 보건소법에서 지역보건법으 로 개정되어 제9조(보건소의 업무)에 마련되어 보건소 사업 중 하나 로서 지속적으로 수행되어왔으며, 현재는 제 11 조(보건소의 기능 및 업무)로 개정되어졌다. ${ }^{27}$ 이후 방문보건사업 또한 방문간호를 포함하 는 가정간호사업을 중심으로 이루어져왔으며 국민건강증진종합계 
획과 별개로 2010-2012년 '방문건강관리사업 연보'를 보면 보건복지 부, 한국건강증진재단과 더불어 서울대학교 간호대학(2010,2011), 제 주대학교 간호대학(2012)'이 함께 발간하여 간호사가 방문건강관리 사업의 중심으로 활동하였음을 알 수 있었다. ${ }^{27-29}$

HP2010-2020사업으로 이어지면서 방문건강관리분야에서 물리치 료사, 작업치료사의 법적역할은 추가되었지만, 지역사회중심재활 사 업에서 실시되고 있는 재활전문가로서의 법적근거는 아직 마련되어 있지 않음을 알 수 있었다. $10,11,13,23$

\section{1) 방문건강관리}

2020년부터는 보건소내의 간호사, 물리치료사, 작업치료사, 치위생사 등의 전문인력이 서비스대상자에게 방문하여 보건소 내외의 자원을 연계하는 건강관리서비스사업으로 다문화가족 및 북한이탈주민에 대한 건강관리서비스제공도 실시할 수 있게 되었다.12,13,22,23

법적근거로는 국민건강 증진법 제 3 조(책임), 보건의료기본법 제 31 조(평생국민건강관리사업), 공공보건의료에 관한 법류 제7조(공공보 건의료기관의 의무), 지역보건법 제 11 조(보건소의 기능 및 업무), 지역 보건법 제 16 조의 2(방문건강관리 전담공무원)이 있다. 보건복지부령 으로 정하는 전문인력을 방문건강관리 전담공무원으로 둘 수 있다.

- 지역보건법 시행규칙 제 4 조의 2(방문건강관리 전담공무원)

2. 의료기사등에 관한 법률」 제 2 조제 2 항제 3 호, 제 4 호 및 제 6 호에 따른 물리치료사, 작업치료사 및 치과위생사

\section{2) 지역사회중심재활}

2017년 장애인 건강권 및 의료접근성 보장에 관한 법률(장애인건강 권법)의 제 7 조(장애인 건강검진사업), 제 8 조(장애인건강관리사업), 제 9 조(장애인의 의료기관 등 접근 및 이용 보장 등), 제 12 조(장애인 건강 보건정보사업), 제 14 조(장애인 건강권 교육), 제 15 조(재활운동 및 체 육) 및 장애인 복지법 제 18 조(의료와 재활치료), 장애인차별금지 및 권 리구제 등에 관한 법률 제 31 조(건강권에서의 차별금지), 개인정보관 련법인 장애인건강권법 시행령 제 10 조(민감정보 및 고유식별정보의 처리)와 개인정보보호법 제 15 조(개인정보의 수집, 이용)가 근거 법률 이었으나, 2020 년에는 공공보건의료에 관한법률 제7조(공공보건의료 기관의 의무)가 주내용이 되고 장애인 건강권 및 의료접근성 보장에 관한 법률이 제7조에서 제 4 조(국가와 지방자치단체의 책무)로 변경 되어 나머지는 제외되면서 아래의 4 개 법률로 법적근거를 두고있다. ${ }^{1}$

법적근거로는 공공보건의료에 관한 법률 제7조, 지역보건법 제 11 조, 장애인 건강권 및 의료접근성 보장에 관한 법률 제 4 조(국가와 지 방자치단체의 책무), 장애인 차별금지 및 권리구제 등에 관한 법률 제 31 조(건강권에서의 차별금지)가 있다.

(1) 중앙장애인 보건의료센터: 장애인 건강권 및 의료접근성 보장
에 관한 법률 제 19 조

(2) 지역장애인 보건의료센터: 장애인 건강권 및 의료접근성 보장 에 관한 법률 제20조

(3) 보건소: 지역보건법 제 11 조

지역사회중심재활사업에서는 방문건강관리사업과 달리 물리치 료사의 업무에 대한 법적근거는 마련되어 있지 않지만, 중앙장애인보 건의료센터, 지역장애인보건의료센터 및 보건소에서 이루어지는 선 택적 방문재활서비스등의 전문의료서비스에 대한 사업은 물리치료 사의 업무에 대한 법률적 근거가 마련되어 있다.

\section{3) 장애인 건강보건관리}

지역사회중심재활사업의 주사업분야로 구성되어 있지만 장애인을 중점으로 두어 건강권 향상과 적정진료와 재활의료제공 등에 사업 의 방향성을 두고 있다. 법률적 근거는 지역사회중심재활과 거의 동 일하지만 전문재활서비스를 제공하는 '장애인보건의료센터(중앙, 지 역)' 지정 및 보건소 사업과 관련된 구체적인 내용에서는 장애인건강 권법 등 개별 지침에 따르고 있다. ${ }^{24}$

법적근거로는 장애인 건강권 및 의료접근성 보장에 관한 법률, 장 애인 차별금지 및 권리구제 등에 관한 법률 제 31 조, 공공보건의료에 관한 법률 제7조, 지역보건법 제 11 조가 있다.

보건소의 지역사회중심재활사업에서는 물리치료사를 재활담당 인력으로 구성을 권장하고 있으나 법률적으로 근거를 두고 있는 것 은 아니며, 시범사업으로서는 방문서비스에서 '장애인 건강주치의 (장애인 건강권법 제16조)'가 방문하는 '방문진료' 간호사가 방문하 는 ‘방문간호'서비스로 구분되어 진행되고 있으며 ‘방문재활서비스는 아직 진행되지 못하고 있다.

\section{19-20대 국회입법안을 통한 분석}

방문재활과 방문물리치료에 대한 각분야에서의 요구에 따라 근거법 률을 마련하기 위하여 대한민국 19대, 20대 국회의 입법과정에서도 관련 의안이 접수되어 처리되지 않고 있다.

국회 의안검색사이트에서 검색한 19 대이후 발의된 의안중에서 방 문재활과 방문물리치료내용을 보면 다음과 같이 다양한 내용으로 발의되었다.

1) 노인복지법

(1) 김상희의원 대표발의(2017. 2. 16)

현행법에서 재활요양에 관해서 별도의 서비스 제공시설을 규정하고 있지 않아 신체적 교정, 정신적 기능장애 등에 대한 재활교육 및 상 담, 운동지도를 전문적이고 체계적인 재활서비스의 필요를 위하여 제 34 조 제4호 노인재활요양시설에 관한 내용을 신설하는 것으로 발 
의하였다. ${ }^{30}$

\section{2) 노인장기요양보험법}

(1) 정청래의원 대표발의(2013. 6. 5)

제 23 조(장기요양급여의 종류) 제 1 항 제 1 호 라. 방문물리치료에 관한 내용 등을 신설하여 방문물리치료의 내용을 추가하도록 하였다. ${ }^{31}$

(2) 기동민의원 대표발의(2016. 12. 28)

2013 년 정청래의원등이 발의한 제 23 조 제 1 항 제 1 호 라목에서 ‘방문간 호지시서'를 '방문재활처방서'로 바꾸고, 제 32 조 제 3 항의 방문재활 관 리책임자를 물리치료사 또는 작업치료사로 규정하는 내용으로 개정 하였다. 그리고 제 42 조와 제 58 조 제 2 항에서도 '방문간호지시서'를 '방 문간호처방서 및 방문재활처방전'으로 개정하는 내용으로 수정하여 발의하였다. ${ }^{32}$

\section{3) 장애인활동지원에 관한 법률}

(1) 인재근의원 대표발의(2019.10.31)

현행법에 활동지원급여가 포함되어 있지 않아 방문물리치료를 추가 함으로써 전문적이고 체계적인 재활서비스를 제공받을 수 있도록 제 2 조 제 2 호에서 '방문간호'를 '방문간호, 방문물리치료'로 수정하고 제 16 조 제 1 항 제 4 호 방문물리치료 내용을 신설하고 '방문간호지시서'를 ‘방문간호처방서 및 방문재활처방전’으로 개정하는 내용으로 수정하 였다. ${ }^{33}$

\section{4) 장애인건강권 및 의료접근성보장에 관한 법률}

(1) 김용익의원 대표발의(2015. 9. 7)

2015. 12.29에 장애인건강권 보장에 관한 법률안 제 10 조 제 2 항에서 국 가와 지방자치단체에서 방문진료사업을 수행하도록 발의하여 '장애 인건강권 및 의료접근성보장에 관한법률(약칭 장애인건강권법)'이 란 이름으로 제정되어 제 9 조 제 2,3 항으로 제정되었다. ${ }^{34}$

국민건강을 위한 정책사업과 개별정책에 따른 근거로써 방문재활, 방문물리치료의 내용들이 포함되어 있으며 2020년부터 시행되는 지 역보건법 제 16 조의 2 방문건강관리 전담공무원내용과 장애인 건강 권 및 의료접근성 보장에 관한 법률 제 19 조, 제 20 조 그리고 지역보건 법 제 11 조 중앙 및 지역장애인 보건의료센터와 보건소를 통한 선택 적 방문재활서비스에 대해서만 법률적으로 명시하고 있다. 시설중심 으로 이루어지는 지역사회중심재활사업에서의 노인복지법 제 30 조 에서는 재활요양사업에 대한 필요성만 기술하고 있으며 자세한 사항 또한 보건복지부령에서 아직 정하지 않고 있다. 노인장기요양보험법 과 장애인활동지원에 관한 법률, 장애인건강권 및 의료접근성보장에 관한 법률에서도 방문재활, 방문물리치료에 대한 필요성이 법률로
만들어져 입법되어있다. 특히, 지역사회재활개념과 관련하여서는 다 면적 법률의 근거를 가지고 접근이 필요한 사용자중심의 시스템이 더욱 중요하다는 것을 보여준다.

\section{고 찰}

본 연구는 자료조사를 통한 연구로서 최근 정책자료와 법률 그리고 입법의안 조사를 통해 방문재활과 물리치료사의 역할에 대한 실태 를 살펴보고자 함이었다. 정책과제로 추진되어온 내용과 국회의 입 법활동을 통한 법률을 분석하여 이전과 다른 새로운 정책과 입법활 동에서 내용을 반영할 수 있도록 하고자 하였다. 최근 국회의 입법활 동에서도 방문재활, 방문물리치료에 대한 지침, 법안이 국민건강증 진계획이라는 정책이란 틀에서 일률적이지 못하고 각각의 근거법률 을 찾아서 제시하거나, 새로운 법안을 만들어 입법예고 하고 있는 것 으로 확인되었다.

시설위주의 현장에서 활동하는 물리치료사들에게는 아직도 지역 사회중심재활은 낮선 용어이며, 무엇을 할 수 있는지 잘 알지못하는 와중에 HP2020 등의 정책뿐만 아니라 19-20대 국회의 입법과정에서 도 재활소비자들의 요구에 의해 노인, 장기요양법, 장애인관련법에서 방문재활, 방문물리치료 관련법안이 발의되었다.

살펴본 바와 같이 정책사업과 그에 따른 근거법률에 방문재활, 방 문물리치료의 내용들이 포함되어 있으나 지역보건법 제 16 조의 2 방 문건강관리 전담공무원내용과 장애인 건강권 및 의료접근성 보장 에 관한 법률 제 19 조, 제 20 조 그리고 지역보건법 제 11 조 중앙 및 지역 장애인 보건의료센터와 보건소의 시설을 통한 선택적 방문재활서비 스에 대해서만 법률적으로 명시하고 있을 뿐이다. 국회에서 최근 19-20대 국회의원 임기동안 방문재활과 방문물리치료에 관한 내용 은 기존내용의 수정과 관련한 내용일 뿐 시설중심의 방문재활에서 사용자중심의 방문재활에 관한 내용에 관한 것은 없다. 더구나 많은 사업들이 법안에 의해 정책들이 만들어 지는 것보다 정책들이 만들 어지면 근거법률을 제시하고 그 후 사업의 원활한 진행을 위해 단독 법안이 만들어지는 과정을 거치기도 한다. 법률이 우선되기보다 정 책사업을 위해서 근거법률을 제시하고 있는데 사용자중심으로 시행 되어야 한다는 방문재활, 방문물리치료에는 정책사업이 보이지 않는 다. 법률적근거를 위해 적합한 과정의 순서에서 잘못하고 있는 것은 아닌지 생각해보아야 할 것이다.

방문재활은 현장에서 서비스당사자들의 필요, 요구에 의해 정책, 법률이 제안되고 있으므로 시설중심재활의 법률인 의료법, 의료기사 법에 대한 수정만으로는 적절치 않다. 사용자중심 체계로 관련 법률 들이 근거를 적절하게 뒷받침해주는 구조로 형성되어야 하며, 물리치 료사의 방문재활에서도 최소한의 일상생활동작 교육과 운동 및 훈련 
을 할 수 있도록 다양한 분야에서 서비스를 요구하고 있다. 그러므로 물리치료사의 업무범위에서 일상생활동작의 교육과 운동, 훈련이 법 령에 포함되도록 여러 조직에서 필요로 할 때 관계법령과 함께 다면 적 확장방식으로 근거법률을 만들어 나가는 것이 필요할 것이다.

이런 다면적 접근은 재난구호 등에 있어서 국제적활동을 하는 적 십자사의 경우에도 활동에 있어 재해구호법 제 2 조, 대한적십자사 조 직법 제 7 조(사업), 긴급구조대응활동 및 현장지휘에 관한 규칙 제 11 조(긴급구조지원기관 등의 역할), 수난구호법 시행령 제 2 조(수난구호 협력기관의 범위), 비상대비자원관리법 제 11 조(중점관리대상자원의 지정), 민방위기본법 시행령 제 14 조(지정행정기관의 장의 범위)등을 국내법적 근거로 두고 있는 것에서도 볼 수 있다.

그러므로 근거법률에서도 단독법안을 만드는 것에만 몰두하는 것 이 아니라 다면적인 정책사업의 개발과 활용을 통해 그에 해당하는 다 면적인 근거법률을 제시할 수 있도록 우선적인 노력이 필요할 것이다.

본 연구의 제한점으로는 입법자료의 참고시점이 국회입법예고시 스템의 상세검색에서 19-20대 국회의 입법자료만 검색이 가능하여, 최근 두 회기의 국회임기동안의 자료만을 참고하였다.

마지막으로, 연구시점이 정책자료인 HP2020 또한 사업적으로 종 결이 되는 시점으로 아직 HP2030 정책에 대한 공모가 마무리되지 않 아 향후의 정책방향에 있어 방문재활과 물리치료사의 역할 등에 대 한 논의를 구체적으로 하지 못하는 점은 아쉬운 부분이었다. HP2030 의 정책자료에 참여하지는 못하였지만 이후에 지속적인 자료검토와 더불어 앞으로 국민건강정책에 있어 방문재활과 물리치료사의 역할 및 법안 개발을 위해 다양한 연구가 지속되어야 할 것이다.

\section{ACKNOWLEDGEMENTS}

본 연구는 대한물리치료사협회 부산시회의 연구비 지원을 받았음

\section{REFERENCES}

1. Korea ministry of health \& welfare, National Rehabilitation Center, Korea health promotion foundation. 2020 Community Integrated Health Promotion Project (CBR). 2019.

2. World Health Organization. Community-based rehabilitation Guidelines. 2010.

3. Lee MY, Chung JJ, Hong HJ et al. Evaluation of the home-based rehabilitation program based on CBR Model through in-depth interviews with visiting physical therapists. J Kor Phys Ther. 2015;27(1):68-77.

4. Kim DM. The Necessity to Introduce Home Visiting Physiotherapy. J Kor Phys Ther. 1996;3(2):997-1009.

5. Han DW, Oh YT, Moon TH et al. Development of the System for Home Visiting Physical Therapy. J Kor Phys Ther. 2005;17(1):99-120.

6. Park SK, Ji HY, Heo JW. Effects of Home Visiting Physical Therapy on Activities of Daily Living and Function in Disabled Persons Living at
Home. J Kor Phys Ther. 2011;23(2):61-8.

7. Hwang BY, Lee EJ, Han SD. Effects of Home Visiting Physical Therapy on Motor Function and ADL in the Persons with Chronic Stroke. J Kor Phys Ther. 2003;15(4):1013-22.

8. Park SK, Heo JW, Yang DJ et al. Effects of Home Visiting Physical Therapy and Environmental Factors Analysis Using International Classification of Functioning, Disability and Health (ICF). J Kor Phys Ther. 2012;24(4):282-9.

9. Korea ministry of health \& welfare, Korea institute for health and social affairs. Establish of new Health Plan 2010. 2006.

10. Korea ministry of health \& welfare. The 3rd. Health plan 2011-2020. 2011.

11. Korea ministry of health \& welfare, Korea health promotion foundation. The 4th. Health plan 2016-2020. 2015.

12. Korea ministry of health \& welfare, Health plan 2010.

13. Korea ministry of health \& welfare, Korea health promotion institute. 2016 Community Integrated Health Promotion Project (Home health care). 2016.

14. Korea ministry of health \& welfare, Korea health promotion institute. 2013 Community Integrated Health Promotion Project (General guide). 2013.

15. Kim DJ. Healthy People 2020: Framework and Implications. Korea institute of health and social affairs. Health and Social Welfare Forum. 2011;2:94-108.

16. Lee HS, Park DM, Kim CS. Home visiting physical therapy. J Kor Phys Ther. 1996;8(1):91-8.

17. Yi CH, Weon JH, Ok JY. House visits by physical therapist and patient needs. Phys Ther Korea. 2000;7(1):64-78.

18. Kim GY, Ahn CS, Jeon HW. A Study on the Introduction of HomeBased Physical Therapy for Patients with Cerebrovascular Disease. J Kor Phys Ther. 2015;27(2):118-23.

19. Korea Physical Therapy Association. Home visit physical therapy practice guideline and program development. KPTA. 2018:2:62.

20. Korea Physical Therapy Association. Development of guidelines for home visit physical therapy. KPTA. 2018:2-44.

21. Seoul National University Bundang Hospital, Korea health promotion foundation. Development of a home-based rehabilitation service model applicable to Korea. 2013.

22. Korea ministry of health \& welfare, Korea health promotion institute. 2011 Community Integrated Health Promotion Project (Home health care). 2011:101-214.

23. Korea ministry of health \& welfare, Korea health promotion institute. 2020 Community Integrated Health Promotion Project (Home health care). 2019.

24. Korea ministry of health \& welfare. 2020 Guide to the Health Care for Persons with Disabilities. 2019.

25. Ahn SH. Analysis of visiting nursing activities in public health centers. Yonsei university. Dissertation of Master's Degree. 2000.

26. Lee, HS, Park DM, Kim CS. Home-visiting physical therapy. J Kor Phys Ther. 1996;8(1):91-8.

27. Korea ministry of health \& welfare, Korea health promotion foundation, Seoul national

28. University college of nursing. 2010 Yearbook of Home visiting health care. 2012.10. 
29. Korea ministry of health \& welfare, Korea health promotion foundation, Seoul national university college of nursing. 2011 Yearbook of Home visiting health care. 2012.10.

30. Korea ministry of health \& welfare, Korea health promotion foundation, Jeju national university college of nursing. 2012 Yearbook of Home visiting health care. 2013.12.

31. Kim SH, Jung CS, Yoon SH et al. Welfare of older persons act: partial amendment (5644), 2017.

32. Chung CR, Kim WN, Lee WW et al. Act on long-term care insurance for older persons: partial amendment (5348), 2013

33. Gi DM, Go YG, Do JH et al. Act on long-term care insurance for older persons: partial amendment (4666), 2016.

34. In JG, Kim CM, Jung CS et al. Act on activity assistant services for persons with disabilities: partial amendment (23458), 2019.

35. Kim YI, Kim SJ, Jin SM et al. Act on guarantee of right to health and access to medical services for persons with disabilities: new enactment (16765), 2015. 